УДК 32:354:342.7

DOI https://doi.org/10.32836/2310-9653-2020-3.19

С. А. Рудий, аспірант

Національної академії державного управління

при Президентові України, лікар загальної практики

\title{
УРАХУВАННЯ ЗАВДАНЬ ЦІЛІ СТАЛОГО РОЗВИТКУ 3 У СТРАТЕГІЧНИХ ДОКУМЕНТАХ УКРАЇНИ ЩОДО ОХОРОНИ ЗДОРОВ'Я
}

Різниия в розумінні термінів та національні особливості врахування й адаптаиії міжнародної редакиії Цілей сталого розвитку можуть призвести до викривлення фінальної иілі та дисбалансу розвитку. На прикладі Цілі сталого розвитку 3 у статті показано вплив коректного розуміння філософї та завдань Цілей сталого розвитку $і$, як наслідок, логічну структуру керівних документів для досягнення завдань та індикаторів Цілей сталого розвитку, яка могла бути застосована.

Резолюиія про затвердження Цілей сталого розвитку на період до 2030 року ухвалена Генеральною Асамблеєю Організаиії Об'єднаних Націй на 70-й сесії. Для досягнення Цілей сталого розвитку Украйна здійснюватиме нові програми і проєкти, які на практиці забезпечать макроекономічну стабільність, екологічний баланс та соиіальну згуртованість. Цілі сталого розвитку слугуватимуть загальною основою для подальших перетворень в Україні.

Міжнародний підхід до проєктування та складу Цілей сталого розвитку (ЦСР) схожсий на компас для глобального співтовариства країн. Упровадження Цілей сталого розвитку значить, щьо країни будуть розробляти національні стратегіі та програми розвитку відповідно до запропонованої структури Цілей сталого розвитку.

Національне та міжнародне законодавство, системи впровадження були порівняні та проаналізовані, щоби побачити, чи є різниця між міжнародним і украӥнським національним тлумаченням, щзо може призвести до неправильного сприйняття під час розроблення та впровадження національних програм.

У національній редакиї Проєкт національної стратегії сталого розвитку України до 2030 року містить іншу систему иілей. Ціль 3 має назву «Стратегічна иіль - подолання бідності та скорочення нерівності, зокрема тендерної», підзавдання, які називаються «операчіийна иіль», а в міжнародній редакиії назва - «Забезпечити здоровий спосіб життя та сприяти добробуту для всіх у будь-якому віиіџ. Така термінологічна відмінність не має особливого значення, проте зовсім різні завдання, які є під ичи номером, та геть інша композиція «завдань» та «індикаторів» створюють чималі труднощі щодо зіставлення наиіональних і міжнародних иілей.

Начіональна система потребує вдосконалення, усі законопроєкти повинні бути перевірені на відповідність Цілям сталого розвитку, дотримання принципів і виконання завдань.

Ключові слова: $S D G$, цүілі сталого розвитку, стратегія сталого розвитку, співпраця.

S. A. Rudyi. Consideration of the objectives of Sustainable Development Goal 3 in strategic documents of Ukraine on health care

The international approach to design and composition of the sustainable development goals (SDG) is like a compass for the country's global commitments and SDGs implementation are the mean that countries will create national strategies and development programmes in line with the proposed structure of the SDGs.

Differences in the understanding of terms and national specifics of applying and adapting the international version of the SDGs might lead to distortions of the final goal and imbalance of development. Looking at SDG3, the article shows the impact of correct understanding of philosophy and objectives of the SDG and, as a result, the logical structure of the guiding documents for achieving the goals and indicators of SDG might be deployed.

The Resolution approving the SDGs by 2030 was adopted by the UN General Assembly at its 70th session. To achieve the SDGs, Ukraine shall implement new programs and projects to ensure macroeconomic stability, environmental balance and social cohesion in practice. The Goals is serving as a common basis for further transformation in Ukraine.

National and international legislation and implementation systems have been compared and analyzed to see whether there are any differences between international and Ukraine national interpretation which potentially may lead to misperceptions when national programmes designing and deploying.

At national level, the SDGs impose to be implemented in accordance with the draft of the National Strategy for Sustainable Development of Ukraine by 2030. The draft contains a different system of SDGs. Thus, the Goal 3 is entitled as "Strategic Goal - Overcoming Poverty and Reducing Inequality, specifically Gender" and sub-objectives called "Operational Goal". Same time, internationally recognised title is - "Ensuring a healthy lifestyle and promoting well-being for all at all ages". While the terminological difference might be less important, but the completely different tasks which are under this Goal number in combination with completely different composition of "tasks" and "indicators" creates considerable difficulties in comparing national and international goals.

The national system has a room for improvement and all draft of the laws should be tested on compliance with or use of the principles and objectives of the SDG.

Key words: SDG, sustainable development goals, sustainable development strategy, cooperation.

Постановка проблеми. У вересні 2015 р. Генеральна Асамблея ООН на 70-й сесії ухвалила резолюцію про затвердження Цілей сталого розвитку (далі - ЦСР) на період до 2030 р. Офіційно зазначені Цілі запроваджені 31 січня 2016 р. Президент України Петро Порошенко у виступі на Асамблеї 27 вересня 2015 р. зазначив, що «для досягнення ЦСР на національному рівні Україна здійснюватиме нові програми і проєкти, які на практиці

(C) С. А. Рудий, 2020 
забезпечать макроекономічну стабільність, екологічний баланс та соціальну згуртованість. ЦСР служитимуть загальною основою для подальших перетворень в Україні». Проте різниця в розумінні термінів та національні особливості врахування й адаптації міжнародної редакції ЦСР можуть призвести до викривлення фінальної цілі та дисбалансу розвитку.

Мета статті - дослідити й узагальнити національні уявлення, поширені в державному управлінні, щодо еволюції розвитку відносин міжнародного та національного державного розуміння ЦСР.

Виклад основного матеріалу. ЦСР - це система рівноправних та взаємоузгоджених міжнародних і національних завдань, які забезпечать економічне зростання, соціальне благополуччя, свідому турботу про довкілля. ЦСР грунтуються на принципах рівності та справедливості, мирного співіснування громад, дотримання прав людини, це заклик до всіх країн визначити пріоритети розвитку на перспективу, з урахуванням національних завдань та глобальних викликів. ЦСР спонукають інвестувати в інновації, ураховувати наукову думку, а також розвивати міжнародне партнерство.

У національній українській редакції Ціль 3 має назву «Міцне здоров’я і благополуччя», назва в міжнародній редакції - «Забезпечити здоровий спосіб життя та сприяти добробуту для всіх у будь-якому віці».

На міжнародному рівні [1] Ціль має такі завдання й індикатори для моніторингу процесу:

\begin{tabular}{|c|c|}
\hline 3.1. Материнська смертність. & $\begin{array}{l}\text { До } 2030 \text { р. зменшити глобальний коефіцієнт смертності серед матерів } \\
\text { до менш ніж } 70 \text { на } 100000 \text { живонароджених. }\end{array}$ \\
\hline $\begin{array}{l}\text { 3.2. Неонатальна } \\
\text { та дитяча смертність. }\end{array}$ & $\begin{array}{l}\text { До } 2030 \text { р. зупинити всі смерті новонароджених та дітей до } 5 \text { років, які можна } \\
\text { попередити, і всі країни мають на меті зменшити смертність новонароджених } \\
\text { як мінімум до } 12 \text { на } 1000 \text { живонароджених дітей та смертність молодших } 5 \text { років } \\
\text { як мінімум до } 25 \text { на } 1000 \text { живонароджених. }\end{array}$ \\
\hline 3.3. Інфекційні хвороби. & $\begin{array}{l}\text { До } 2030 \text { р. припинити епідемії СНІДу, туберкульозу, малярії та занедбаних } \\
\text { тропічних захворювань, а також боротьбу з гепатитом, захворюваннями, що } \\
\text { передаються з водою й іншими заразними хворобами. }\end{array}$ \\
\hline 3.4. Неінфекційні захворювання. & $\begin{array}{l}\text { До } 2030 \text { р. зменшити на третину передчасну смертність від неінфекційних } \\
\text { захворювань шляхом профілактики та лікування, а також сприяти психічному } \\
\text { здоров’ю та добробуту (індикатор - рівень самогубств). }\end{array}$ \\
\hline $\begin{array}{l}\text { 3.5. Зловживання } \\
\text { наркотичними речовинами. }\end{array}$ & $\begin{array}{l}\text { Посилити запобігання та лікування наркоманії, включаючи зловживання } \\
\text { наркотиками та шкідливе вживання алкоголю. }\end{array}$ \\
\hline 3.6. Дорожній рух. & $\begin{array}{l}\text { До } 2020 \text { р. удвічі зменшити кількість загиблих у світі та постраждалих } \\
\text { від дорожньо-транспортних пригод. }\end{array}$ \\
\hline $\begin{array}{l}\text { 3.7. Статеве та репродуктивне } \\
\text { здоров’я. }\end{array}$ & $\begin{array}{l}\text { До } 2030 \text { р. забезпечити універсальний доступ до послуг сексуального та } \\
\text { репродуктивного здоров’я, включаючи планування сім'ї, інформацію й освіту, } \\
\text { інтеграцію репродуктивного здоров'я в національні стратегії та програми. }\end{array}$ \\
\hline $\begin{array}{l}\text { 3.8. Універсальне охоплення } \\
\text { здоров'я. }\end{array}$ & $\begin{array}{l}\text { Досягти загального медичного покриття, включаючи захист фінансових ризиків, } \\
\text { доступ до якісних основних медичних послуг та до безпечних, ефективних, якісних } \\
\text { і доступних для всіх основних медикаментів та вакцин. }\end{array}$ \\
\hline $\begin{array}{l}\text { 3.9. Охорона навколишнього } \\
\text { середовища. }\end{array}$ & $\begin{array}{l}\text { До } 2030 \text { р. істотно скоротити кількість смертей та захворювань від небезпечних } \\
\text { хімічних речовин і забруднення повітря, води та грунту, а також забруднення. }\end{array}$ \\
\hline \multicolumn{2}{|r|}{ Мета 3 - Засоби реалізації цілей } \\
\hline 3.а. Контроль над тютюном. & $\begin{array}{l}\text { Посилити імплементацію Рамкової конвенції Всесвітньої організації охорони } \\
\text { здоров’я про боротьбу з тютюном у всіх країнах, якщо це доречно. }\end{array}$ \\
\hline 3.b. Ліки та вакцини. & $\begin{array}{l}\text { Підтримувати дослідження та розроблення вакцин і лікарських засобів проти } \\
\text { інфекційних та неінфекційних захворювань, які вражають насамперед країни, } \\
\text { що розвиваються. Забезпечити доступ до доступних основних лікарських засобів } \\
\text { та вакцин відповідно до Дехської декларації про торговельні аспекти прав } \\
\text { інтелектуальної власності та громадське здоров'я, яка підтверджує право країн, } \\
\text { що розвиваються, на повне використання положень Угоди про торговельні аспекти } \\
\text { прав інтелектуальної власності (угода TRIPS) щодо гнучкості для охорони здоров'я } \\
\text { населення і, зокрема, забезпечення доступу до медикаментів для всіх. }\end{array}$ \\
\hline $\begin{array}{l}\text { 3.c. Фінансування охорони здоров’я } \\
\text { та робоча сила. }\end{array}$ & $\begin{array}{l}\text { Суттєво збільшити фінансування охорони здоров’я та набору, розвитку, навчання } \\
\text { й утримання медичної робочої сили у країнах, що розвиваються, особливо } \\
\text { в найменш розвинених країнах та малих острівних державах, що розвиваються. }\end{array}$ \\
\hline $\begin{array}{l}\text { 3.d. Підготовка до надзвичайних } \\
\text { ситуацій. }\end{array}$ & $\begin{array}{l}\text { Посилити потенціал усіх країн, зокрема країн, що розвиваються, } \\
\text { щодо раннього попередження, зменшення ризиків і управління } \\
\text { національними та глобальними ризиками для здоров’я. }\end{array}$ \\
\hline
\end{tabular}


Проєкт Національної стратегії сталого розвитку України до 2030 р. [2] містить зовсім іншу, національно специфічну систему ЦСР. Так, Ціль 3 має назву «Стратегічна ціль - подолання бідності та скорочення нерівності, зокрема гендерної», підзавдання, які називаються «операційна ціль». Така термінологічна відмінність не має особливого значення, проте зовсім різні завдання, які є під цим номером, та геть інша композиція «завдань» та «індикаторів» створюють чималі труднощі щодо зіставлення національних і міжнародних цілей.

Питання охорони здоров’я віднесені до «Стратегічної цілі 4 - забезпечення охорони громадського здоров’я, благополуччя та якісної освіти в безпечних і життєстійких населених пунктах». Порівняння лише назв завдань викликає питання щодо принципів реорганізації та групування цілей. «Операційні цілі» (далі - ОЦ) скидаються на специфічну комбінацію інтернаціональної версії ЦСР (SDG) 3, 4 та 11. ОЦ 4.1. Забезпечити охорону громадського здоров'я та сприяти благополуччю для всіх у будь-якому віці (SDG 3.8); 4.2. Забезпечити інклюзивну та справедливу якісну освіту і сприяти можливостям навчатися впродовж усього життя для всіх (SDG 4); 4.3. Зробити міста та населені пункти інклюзивними, безпечними, життєстійкими та збалансованими (SDG 9). Варто зазначити, що в цій редакції ОЦ 4.2 та 4.3 взагалі не мають відповідника в інтернаціональній інтерпретації ЦСР, що, напевно, буде створювати диспропорції під час імплементації, зіставлення зі світовим досвідом і звітування.

Беручи до уваги, що ЦСР - це система рівноправних та взаємоузгоджених цілей і завдань, які в разі акуратного виконання приведуть до гармонійного та постійного розвитку, варто звернути увагу на розуміння перекладу англійського слова sustainable, правильне розуміння якого дозволить осягнути саму сутність системи ЦСР. У простому перекладі воно значить «стійкі», почасти сприймається як такі, що можуть протистояти стороннім, негативним впливам.

Тлумачний онлайн-словник «Кембридж» [3] визначає sustainable як такий, «що завдає незначної шкоди навколишньому середовищу або не спричиняє цього, і тому може тривати довгий час». Така різниця у трактуванні терміна призводить до різних методів та напрямів планування.

У ст. 2, п. 2 ст. 19 Конституції України зазначено, що будь-яка державна організація чи урядова організація повинна керуватися правилами та методами, встановленими законами та законодавством України. Отже, будь-який державний орган розпочне роботу з коригування, адаптації та впровадження ЦСР після того, як Уряд надасть відповідне розпорядження виконавчим державним органам.

У лютому 2016 р. на вимогу Міністерства економічного розвитку і торгівлі (далі - МЕРТ) Уряд доручив іншим міністерствам розпочати адаптацію ЦСР у відповідних областях управління та створити технічну робочу групу (далі - ТРГ). МЕРТ має організовувати щоденне управління роботою ТРГ та звітувати перед Урядом щоквартально. Проте звітів у відкритому доступі поки немає. Через різні причини органи влади більше не повертались до питання імплементації ЦСР.

Нормотворча думка народних депутатів (О.А. Недава, А.В. Бабак, О.В. Співаковський, О.В. Кірш) створила проєкт закону України «Про Стратегію сталого розвитку України до 2030 р.» від 7 серпня 2018 р. № 9015 [4]. Документ майже цілком повторює Національну стратегію [2], її композицію.

Про стан впровадження ЦСР та стан державного управління реалізацією ЦСР свідчить висновок Головного науково-експертного управління Верховної Ради України (далі - ВРУ) [5]: «Представлений проєкт Стратегії є документом довгострокового програмування та планування <.. > Документ, який пропонується схвалити в даному проєкті, за своїм змістом (після належного доопрацювання) скоріше може бути класифікований як державна цільова програма». Така дискоординація із чинним законодавством є потужним сигналом, щоб пильніше працювати над адаптацією ЦСР в українському соціальному розвитку.

Державна політика, управління та стратегія реалізації ЦСР в Україні мають широке коло потенційних партнерів, до яких належать владні структури на національному та місцевому рівнях, законодавці, громадські організації, міжнародні агенції та донори.

На національному рівні це Верховна Рада України, яка має вирішальну роль в імплементації ЦСР в Україні шляхом створення й удосконалення національного законодавства, Уряд України, що складається з Кабінету Міністрів (прем’єр-міністр, віце-прем’єр-міністри, 20 міністрів та керівників урядових органів), секретаріату Кабінету Міністрів та відповідних міністерств і відомств, з урахуванням територіальних відділень центральних органів виконавчої влади.

На місцевому рівні - це представницькі та виконавчі органи місцевого самоврядування.

Кабінет Міністрів (далі - КМ) забезпечує загальну координацію між міністерствами та відомствами, стратегічне планування та моніторинг упровадження, адаптацію спільного бачення та проєкти рішень Уряду.

Партнерами, які можуть прискорити ЦСР, є:

I. Департаменти секретаріату КМ, якого найбільше стосується реалізація ЦСР: 1) стратегічне планування та координація державної політики; 2) фінансово-економічний розвиток; 3) гуманітарна та соціальна політика - відповідають за розроблення державної політики, координацію відповідних суб'єктів і управління згідно iз загальним вектором розвитку країни. Ці департаменти є основними рушійними силами в адміністративній 
структурі управління КМ, на яку покладено обов'язок керувати ЦСР серед міністерств та державних установ. Департаменти мають потужний важіль для управління інституціоналізацією ЦСР через державні органи.

II. Міністерства, відповідальні за ЦСР в Україні: 1. Економічний розвиток і торгівля (головний орган уряду); 2. Навколишнє середовище; 3. Соціальна політика; 4. Освіта та наука; 5. Сільське господарство; 6. Енергетика та вугільна промисловість; 7. Регіональний розвиток, будівництво та житлово-комунальне господарство; 8 . Закордонні справи; 9. Правосуддя; 10. Внутрішні справи; 11. Здоров’я; 12. Фінанси; 13. Культура.

Отже, тринадцять із вісімнадцяти міністерств цілком відповідають за ЦРТ. Побічно, але добре залучені міністерства: а) спорту; б) інформаційної політики; в) інфраструктури; г) тимчасово окупованих територій; г) оборони.

III. Державні комітети підпорядковуються певним міністерствам, відповідають за точно визначені завдання, повинні розглядатися як віддалена частина міністерств.

IV. Державні установи координуються секретаріатом КМ України для реалізації перехресних питань ЦСР в аспектах державного управління: а) Державне агентство з водних ресурсів; б) Державна комісія з регулювання енергоресурсів; в) Державне агентство з риболовних ресурсів; г) Фонд безробіття; г) Фонд соціального забезпечення; д) Пенсійний фонд.

V. Бізнес-асоціації - це добровільне об'єднання різних прибуткових організацій для накопичення ресурсів та просування і захисту бізнесу. Впливові, потужні й орієнтовані на майбутнє промисловці та виробники найбільше захоплені розробками, інноваціями та соціальним впливом/відповідальністю. Багато членів асоціацій мають власні стратегії соціальної відповідальності та щорічно виділяють кошти на реалізацію. Учасники не захоплюються лише ЦСР, але отримують додатковий прибуток від вищого рейтингу під час торгів на IPO та на акціях. Соціальна відповідальність та прихильність до належних економічних і екологічних принципів можуть бути яскравою ознакою бізнесу, що процвітає.

Деякі асоціації вже активні у просуванні ЦСР, деякі - ще не активні. Активні такі:

1. Компанія ООН Global Compact - спеціальна агенція всередині ООН для розвитку співпраці з бізнесом. Агентство має надійний досвід взаємодії з національним бізнесом, знання кращих практик у світі. В Україні Global Compact організував нараду з підвищення обізнаності ЦСР для малого та середнього бізнесу, має стратегічне бачення методів залучення бізнесу.

2. Свропейська бізнес-асоціація, приєднується до національного та європейського бізнесу, робить свій внесок у низку ЦСР, удосконалює та розвиває комунікацію між членами та зацікавленими сторонами.

Асоціації, які можуть бути партнерами з розвитку:

1. Українська ліга промисловців та підприємців, створена в 1992 р., має 28 регіональних представництв по всій Україні та приєдналася до понад 100 громадських організацій. Найвідоміші та найпотужніші серед них такі: Український союз хіміків, Асоціації міжнародних автомобільних перевізників, «Меблідеревпром», «Укроїлпром», Асоціація виноградарів та виноробів України, Ліга виробників нафти України, Українська аграрна конфедерація. Наближаючись до ULIE, ПРООН створить приміщення для дискусій та співпраці з найбільшими рушіями економічного зростання в Україні, розвиватиме цілі розвитку, пов’язані з економікою, безробіттям, соціальним забезпеченням та рівністю, довкіллям тощо.

2. Асоціація експедиторів України, створена для захисту прав експедиторів, упровадження якості послуг світового рівня, підвищення кваліфікації фахівців галузі, застосування антикорупційних принципів у сфері перевезень, інтеграції українських компаній, що виходять на міжнародний ринок, співпрацюють із законодавчими органами щодо ситуації в галузі.

3. Асоціація ІТ-компаній України, утворена з метою розвитку внутрішньої IT-індустрії та підвищення продуктивності членів.

Десятки інших подібних спілок, ліг та асоціацій є об'єднаними дуже ініціативними та відкритими компаніями, які можуть виступати за СГД.

VI. НУО та платформи. Партнерство з неурядовими організаціями та платформами може принести нові ідеї для адвокації й обміну знаннями, стимулювати міжособистісну комунікацію та підвищити видимість зусиль ПРООН у просуванні ЦПР в Україні. Найвідоміші такі:

1. «Гурт», неурядова організація, яка керує добре відомим національним інформаційним вебсайтом. Складається $з$ понад 35 тис. інституційних та індивідуальних членів. Забезпечує тематичний обмін повідомленнями, співпрацює $з$ деякими урядовими установами в галузі належного управління, освіти, розвитку дослідницьких навичок для органів місцевого самоврядування. На вебсайті щомісяця розміщується приблизно 80 повідомлень про цілі SDG. Що стосується проєкту, то це може бути корисно для обміну знаннями, тренінгів / оголошення подій, написання блогів.

2. Вебпортал «Громадська область», об’єднує понад 350 тис. членів громадських організацій, пропонує різні види навчання, інструменти для розвитку організаційного потенціалу й особистих навичок, здійснює міжвідомчу співпрацю в Україні та на місцевому рівні.

3. «Прометей», національний лідер онлайн-освіти, співпрацює з різними університетами, може надати підтримку розвитку онлайн-освіти. 
4. Академія державно-приватного партнерства - це некомерційна громадська організація, яка є приєднаною організацією ЄЕК ООН, яка діє в галузі підготовки та технічної допомоги місцевим структурам і структурам самоврядування.

5. Харківська група із захисту прав людини, потенційно добрий захисник ЦСР через аспекти прав людини. Може залучати європейські ОГС для участі у просуванні, навчанні та пропагандистських заходах в Україні. Група зосереджується на трьох основних сферах, як-от: підтримка людей у розслідуванні; освіта та підвищення обізнаності із прав людини; аналіз прав людини в Україні.

Іншим типом платформ є спілки - це організації національного рівня місцевих парламентів або мери. Особливістю цих об’єднань є збереження реальної влади й ефективний вплив на місцеві події, добре знання місцевих потреб, законність використання бюджетних та людських ресурсів. Будучи обраним місцевим населенням, мери міст мають мандат представляти громаду, виступати від іiі імені на будь-якому рівні. Профспілка прихильників місцевого розвитку виступає перед керівництвом Комітету, з огляду на тенденцію до децентралізації, стає більш відповідальною за місцеву економіку, рівень зайнятості, навколишнє середовище та майже всі інші ЦСР.

6. Асоціація міст України, Українська ліга районних та обласних парламентів. Це найпотужніші спілки органів місцевого самоврядування та представників, які юридично та стабільно взаємодіють з урядами національного рівня, місцевими виборними органами / парламентами та різними типами бізнесу в регіонах. Співпраця із цими організаціями, безумовно, стимулює діяльність на місцевому та національному рівнях щодо коригування та впровадження ЦСР.

VII. Навчально-дослідницькі установи. Великий рівень наукової підтримки та розробки рішень. Належне застосування досліджень підвищить реалістичність та доцільність цілей і завдань на національному рівні, забезпечить точний моніторинг і оцінку впровадження ЦСР в Україні.

1. Національний технічний університет України «Київський політехнічний інститут імені Ігоря Сікорського», Всесвітній центр обробки даних щодо ЦСР. Центр координував, сприяв «Доктрині розвитку України до 2030 р.», яка була представлена в Києві наприкінці травня 2017 р. Доктрина була спільно розроблена багатьма вченими, органами ООН в Україні, Київським національним університетом, Національною академією наук, депутатами парламенту й іншими. Автори застосовували метод «Форест-економіки України» до 2020 та до 2030 рр.

2. Молодіжна академія наук України - сприяє науковим дослідженням молодих учених у галузі ЦСР.

За підтримки ПРООН в Україні проведений пілотний проєкт із локалізації ЦСР у Дніпропетровській та Волинській областях. Розроблені й ухвалені місцеві стратегії виконання ЦСР та прогнозні індикатори [6].

Висновки з дослідження і перспективи подальших розвідок у цьому напрямі. ЦСР - компас глобальних зобов'язань країни, полягають у тому, що країни розроблятимуть національні стратегії та програми розвитку; стратегії сталого розвитку, керовані національною власністю та країнами, вимагають мобілізації ресурсів та стратегій фінансування.

3 огляду на вищезазначені ідеї та принципи можна розробити такі рекомендації.

Посилити співпрацю з Урядом, бізнесом та НУО шляхом створення відповідних робочих груп і регулярних зустрічей. Однією із цілей є встановлення преференцій для бізнесу, який добровільно заявляє про прихильність до певних ЦСР. Уряд може підтримувати такі компанії для розвитку експорту, міжнародного співробітництва чи інших непрямих стимулів. Безумовно, треба розробити багато нормативно-правових актів, у Уряд повинен створити інструкції для торгових місій та МЕРТ, як підтримувати підприємства, які добровільно заявляють про прихильність до ЦСР і впевнені в цьому.

Створити міжвідомчий урядовий комітет для координації впровадження ЦСР, призначити МДЕТ технічним і адміністративним координатором.

Усі проєкти законів повинні пройти перевірку на відповідність принципам і цілям ЦСР, потрібні тренінги для місцевих адміністрацій для розвитку навичок оцінки потреб та подання запиту на фінансування.

Переглянути активні постанови Уряду, які регулюють промисловий, соціальний чи економічний розвиток, оновити відповідно до національної версії цілей ЦСР, провести зустріч із зацікавленими сторонами, щоб представити досягнення й ідеї щодо ЦСР в Україні та розробити спільне бачення стратегії впровадження.

Залучити технічну й експертну підтримку Державної служби статистики для покращення вкладу держави в моніторинг і оцінку ЦСР.

Діяльність та співпраця з бізнес-асоціаціями, неурядовими організаціями та платформами можуть бути вигідною угодою із просуванням ЦСР, створювати цінний тиск на власників владних структур для покращення економічного та соціального життя шляхом упровадження та моніторингу ЦСР.

\section{Список використаних джерел:}

1. BOO3.URL:http://www.euro.who.int/en/health-topics/health-policy/sustainable-development-goals/sustainabledevelopment-goals-sdgs/targets-of-sustainable-development-goal-3 (дата звернення: 20.05.2020).

2. ООН в Україні. URL: https://www.undp.org/content/dam/ukraine/docs/SDGreports/UNDP_Strategy_ v06-optimized.pdf (дата звернення: 20.05.2020). 
3. Кембридж : онлайн-словник. URL: https://ictionary.cambridge.org/dictionary/english/sustainable (дата звернення: 20.05.2020).

4. Про Стратегію сталого розвитку України до 2030 р. : проєкт закону України № 9015. URL: http://search. ligazakon.ua/__doc2.nsf/link1/JH6YF00A.html (дата звернення: 20.05.2020).

5. Висновок на проект Закону України / Головне науково-експертне управління BP України. URL: http://search.ligazakon.ua/1_doc2.nsf/link1/XH6YF00A.html (дата звернення: 20.05.2020).

6. Цілі сталого розвитку: Дніпро-2030 : регіональна доповідь, UNDP, GIZ, 2018. URL: https://www.undp. org/content/dam/ukraine/docs/SDGreports/\%d0\%a0\%d0\%b5\%d0\%b3\%d0\%b8\%d0\%be\%d0\%bd\%d0\%b0\%d0 $\%$ bb $\%$ d $1 \% 8 \mathrm{c} \% \mathrm{~d} 0 \% \mathrm{bd} \% \mathrm{~d} 0 \% \mathrm{~b} 0 \% 20 \% \mathrm{~d} 0 \% \mathrm{~b} 4 \% \mathrm{~d} 0 \% \mathrm{be} \% \mathrm{~d} 0 \% \mathrm{bf} \% \mathrm{~d} 0 \% \mathrm{be} \% \mathrm{~d} 0 \% \mathrm{~b} 2 \% \mathrm{~d} 1 \% 96 \% \mathrm{~d} 0 \% \mathrm{~b} 4 \% \mathrm{~d} 1 \% 8 \mathrm{c} \% 20$ \%d0\%94\%d0\%bd\%d1\%96\%d0\%bf\%d1\%80\%d0\%be.pdf (дата звернення: 20.05.2020).

\section{References:}

1. WHO. Web resurs. URL: http://www.euro.who.int/en/health-topics/health-policy/sustainable-development-goals/ sustainable-development-goals-sdgs/targets-of-sustainable-development-goal-3 (last accessed 20.05.2020)

2. The UN in Ukraine. Web resurs. URL: https://www.undp.org/content/dam/ukraine/docs/SDGreports/UNDP Strategy_v06-optimized.pdf (last accessed 20.05.2020)

3. Cambridge online dictionary. Web resurs. URL: https://dictionary.cambridge.org/dictionary/english/sustainable (last accessed 20.05.2020)

4. Bill of Ukraine "Pro Stratehiiu staloho rozvytku Ukrainy do 2030" reg № 9015, URL: http://search.ligazakon. ua/1_doc2.nsf/link1/JH6YF00A.html (last accessed 20.05.2020)

5. Holovne naukovo-ekspertne upravlinnia VR Ukrainy. Vysnovok na proekt Zakonu Ukrainy № Web resurs. URL: http://search.ligazakon.ua/__doc2.nsf/link1/XH6YF00A.html (last accessed 20.05.2020)

6. Tsili staloho rozvytku: dnipro-2030. Rehionalna dopovid, UNDP, GIZ, 2018. Web resurs. URL: https://www. undp.org/content/dam/ukraine/docs/SDGreports/\%d0\%a $\% \mathrm{~d} 0 \% \mathrm{~b} 5 \% \mathrm{~d} 0 \% \mathrm{~b} 3 \% \mathrm{~d} 0 \% \mathrm{~b} 8 \% \mathrm{~d} 0 \% \mathrm{be} \% \mathrm{~d} 0 \% \mathrm{bd} \% \mathrm{~d} 0 \% \mathrm{~b} 0 \%$ d0\%bb\%d1\%8c\%d0\%bd\%d0\%b0\%20\%d0\%b4\%d0\%be \%d0\%bf \%d0\%be \%d0\%b2\%d1\%96\%d0\%b4\%d1\%8c\%20 $\% \mathrm{~d} 0 \% 94 \% \mathrm{~d} 0 \% \mathrm{bd} \% \mathrm{~d} 1 \% 96 \% \mathrm{~d} 0 \% \mathrm{bf} \% \mathrm{~d} 1 \% 80 \% \mathrm{~d} 0 \%$ be.pdf (last accessed 20.05 .2020 ) 